\title{
Neoarchean to Paleoproterozoic fragments in the Brunovistulia terrane, S Poland: a component of the Columbia Supercontinent?
}

\author{
Andrzej ŻELAŹNIEWICZ ${ }^{1, *}$ and C. Mark FANNING ${ }^{2}$ \\ 1 Institute of Geological Sciences PAS, Podwale 75, 50-449 Wrocław, Poland \\ 2 Research School of Earth Sciences, the Australian National University, Canberra, Australia
}

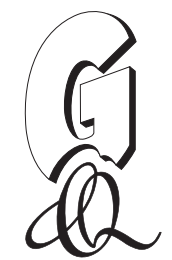

Żelaźniewicz, A., Fanning, C.M., 2020. Neoarchean to Paleoproterozoic fragments in the Brunovistulia terrane, S Poland: a component of the Columbia Supercontinent? Geological Quarterly, 64 (1): 120-129, doi: 10.7306/gq.1515

The composite terrane of Brunovistulia includes basement of the Upper Silesia Block, southern Poland. In its NE part, the basement is elevated by the Rzeszotary Horst. In the Rzeszotary 2 borehole (Rz2) drilled in the horst, partly migmatized amphibolites, felsic gneisses and granites occur. An Na-plagioclase-phengite-K-feldspar neosome contained zircons that yielded U-Pb SHRIMP ages $\sim 2.75-2.6 \mathrm{Ga}$ (cores and single grains) and $\sim 2.0 \mathrm{Ga}$ (rims and single grains). The older ages are interpreted as the time of origin of the igneous protolith of the migmatized amphibolites. The younger ages recorded metamorphism and migmatization that affected both the magmatic precursor of the amphibolites and accompanying felsic rocks during a contractional tectonic/orogenic event. Migmatization was greatly enhanced by an influx of alkali-bearing fluids which heralded intrusion of late-orogenic unfoliated K-granite in an extensional regime, terminating the $2.0 \mathrm{Ga}$ event. It is proposed that the entire orogenic edifice, of which the Brunovistulian rocks drilled in Rz 2 are a small part, represents fragments of the Columbia Supercontinent that was assembled in the Paleoproterozoic and broken up in the Mesoproterozoic. In Ediacaran times, these fragments became eventually incorporated into the Cadomian orogen in the form of its foreland and contributed to the formation of the composite terrane of Brunovistulia. Such a scenario explains why the U-Pb zircon age spectra in the Rzeszotary terrain differ dramatically from those in the remainder of Brunovistulia, which is thought to be the Cadomian hinterland.

Key words: Brunovistulia, Cadomian, Columbia, migmatite, zircon.

\section{INTRODUCTION}

In the Upper Silesia Block (USB), southern Poland, Precambrian rocks are known from the subsurface as granites, gneisses and phyllites discordantly overlain by Lower Cambrian (sub-Holmia) sandstones (Buła et al., 1997, 2008; Buła and Żaba, 2005). The crystalline rocks are interpreted as the basement of the Brunovistulia terrane (Dudek, 1980; Nawrocki et al., 2004) and assigned to the Cadomian orogen because of 580-545 Ma U-Pb ages of zircons retrieved from the unfoliated (late/post-tectonic) granites (Żelaźniewicz et al., 2009). Besides the Ediacaran granites and gneisses, in the eastern part of the USB, metabasites associated with a variety of (meta)felsic rocks were found in the Rzeszotary 2 borehole (Fig. 1) drilled in the concealed Rzeszotary Horst (Konior, 1974; Heflik and Konior, 1974; Buła, 2000; Żelaźniewicz et al., 2009). Preliminary dating of gneisses and amphibolites from the Rzeszotary 2 borehole revealed a U-Pb zircon age of $2.7 \mathrm{Ga}$ for the igneous protolith of felsic rocks of the former (Bylina et al.,

\footnotetext{
* Corresponding author, e-mail: pansudet@pwr.wroc.pl
}

Received: October 18, 2019; accepted: December 17, 2019; first published online: February 27, 2020
2000). Such data indicated the presence of an edifice of at least Neoarchean age, or rather a fragment of it, in the USB basement, which thus contains the oldest rocks in Poland. To check this notion, U-Pb zircon SHRIMP analyses were made of an unfoliated granite vein and neosome rock from migmatized amphibolites drilled in the Rzeszotary 2 borehole (Rz2). The results obtained have implications for the provenance of Brunovistulia and for features of the Cadomian orogen.

\section{GEOLOGICAL FRAMEWORK}

Brunovistulia (Dudek, 1980; Nawrocki et al., 2004) is a composite terrane, with mainly Neoproterozoic basement, accreted to the southwestern margin of Baltica in central Europe (Fig. 1A). It is composed of crustal pieces of Gondwanan descent which once belonged to the Cadomian orogen of Andean type (Finger et al., 2000; Kalvoda et al., 2003, 2008; Żelaźniewicz et al., 2009; Hanžl et al., 2019). Brunovistulia is identifiable up to the Balkans mainly by subsurface investigations (Haydutov and Yanev, 1995; Kalvoda et al., 2008). In its Upper Silesian part, fragments of both the Cadomian hinterland and foreland have been recognized (Buła et al., 2008; Żelaźniewicz et al., 2009). A foreland basement (Fig. 1B) was encountered in the Rzeszotary Horst. In 1909, only a few metres of greenschist and muscovite orthogneiss were drilled 


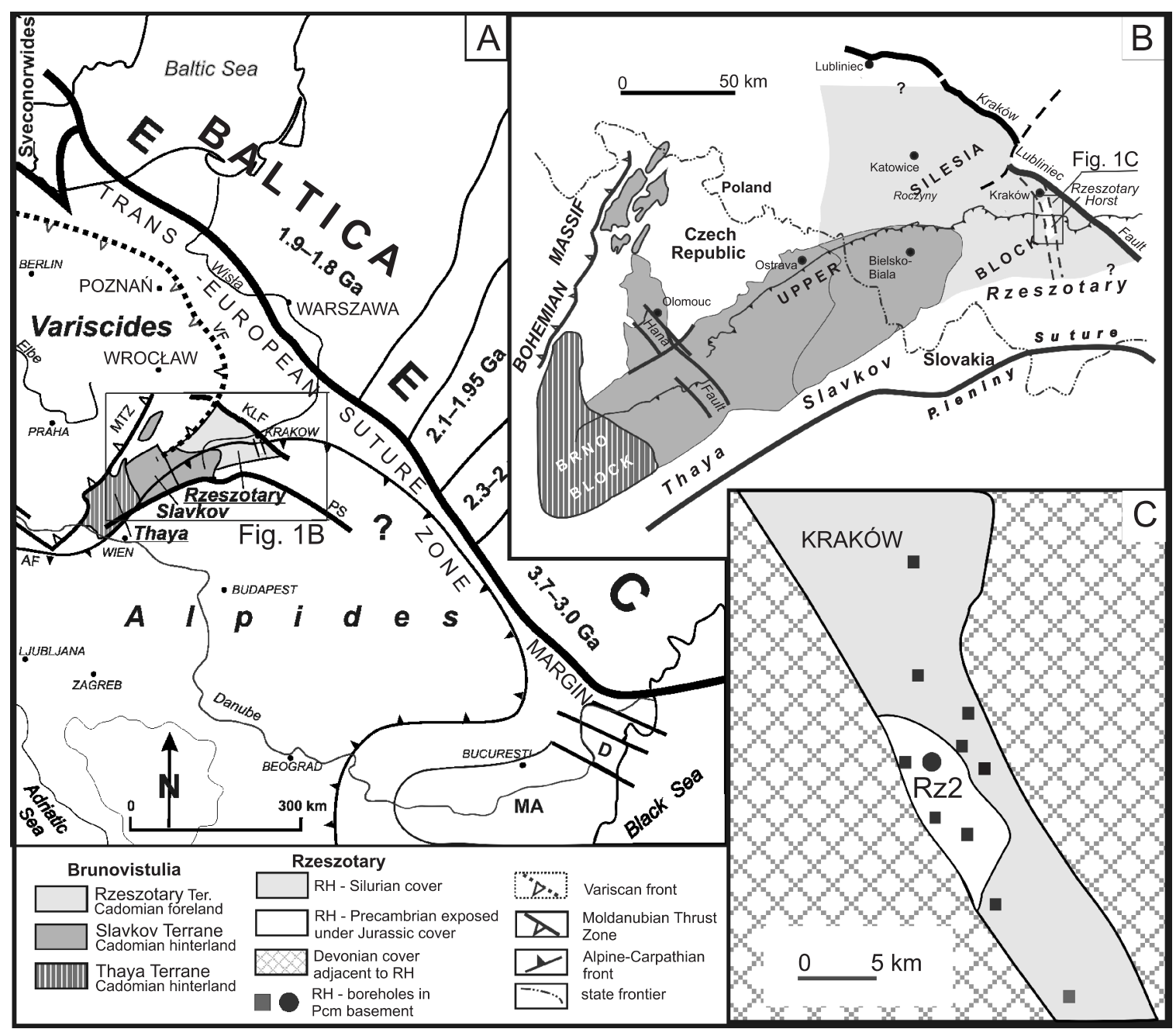

Fig. 1A - location of Brunovistulia (box) within a tectonic sketch of central Europe (Żelaźniewicz et al., 2009; age data after Bogdanova et al., 2008); EEC - East European Craton, D - Dobrogea, KLF - Kraków-Lubliniec Fault Zone, MTZ Moldanubian Thrust Zone, M - Moesia, VF - Variscan Front; B - Brunovistulia; C - Rzeszotary Horst (light grey) with apical part (white) exposed at the Mid-Jurassic palaeosurface, flanked by Devonian carbonates (grid); Rzeszotary 2 borehole (dot), other boreholes (squares), modified after Konior (1974)

in the Rzeszotary 1 borehole and thus the provenance of these rocks has been variously interpreted (Petrascheck, 1909; Nowak, 1927). In 1960-1961, the Rzeszotary 2 borehole was drilled $200 \mathrm{~m}$ east of the earlier one. In Rzeszotary 2 , a $118 \mathrm{~m}$ thick fragment of the crystalline basement (top at $\sim 845 \mathrm{~m}$ b.t.I.) was penetrated below a Middle Jurassic-Cretaceous platform cover in turn overlain by Miocene deposits of the West Carpathian Foredeep and overthrust by nappes of the Alpine system (Burtan, 1962). Felsic crystalline rocks of the Rzeszotary Horst were penetrated by another dozen boreholes (Fig. 1C) though at greater depths (Konior, 1974). Amphibolites were found only in the Rzeszotary 2 borehole, which corroborates potential field data. On magnetic maps (Cieśla et al., 1993), the horst area coincides with a distinct low $(\sim-50 \mathrm{nT})$. On the gravimetric maps (Królikowski and Petecki,
1995), it overlaps with a small local high (3-4 mgal) that fits well the inferred basement elevation in the Rzeszotary Horst.

Timing of the horst origin remained unclear. Crystalline rocks found in Rzeszotary 2 were interpreted as a preHercynian succession of "...more or less diaphtoretically altered amphibolites and gneisses injected with feldspars and subjected to granitization, likely forming a mantle to a more deeply seated granite body..." (Burtan, 1962). Recent re-examination of still available Rzeszotary 2 core revealed a wider variety of gneisses, granites and migmatized amphibolites (Fig. 2).

Plagioclase-muscovite ( $\left.p l-m s^{1}\right)$ gneisses (Fig. 3A), predominant at a depth of $~ 845-887 \mathrm{~m}$, are composed of albite (An $<10)^{2}$ and quartz with subordinate phengitic muscovite (Si apfu $<3.5$ ), minor calcite, rare epidote (Ps >10), and relics of garnet and $\mathrm{Al}_{2} \mathrm{SiO}_{5}$ (kyanite?) phase. The plagioclase is generally poor

${ }^{1}$ Mineral abbreviations after Whitney and Evans (2010);

${ }^{2}$ Chemical compositions of mineral phases were determined with the CAMECA SX-100 electron microprobe facility at the Interinstitutional Laboratory of Microanalysis at the Institute of Geochemistry, Mineralogy and Petrology, Faculty of Geology, Warsaw University 


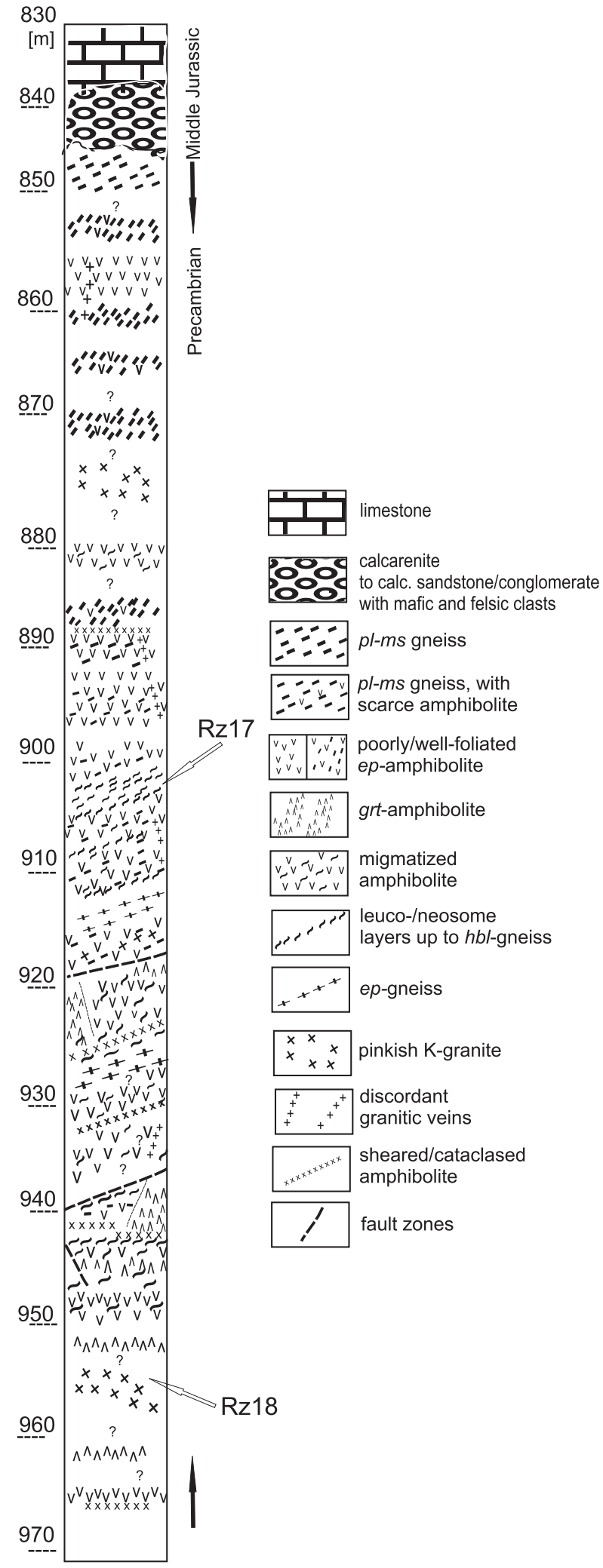

Fig. 2. Lithological log of the Rzeszotary 2 borehole with location of geochronological samples (Rz17, Rz18)

in inclusions. Foliation is expressed by mica flakes and alternating plagioclase-rich $(p />q z)$ and quartz-rich $(q z>p /)$ layers. These rocks were described earlier as "muscovite schists and feldspar-muscovite gneisses" (Burtan, 1962).
Epidote (ep) gneisses (Fig. 3B) consist of plagioclase and quartz accompanied by abundant phengitic mica and epidote whereas K-feldspar, calcite, garnet, biotite, rutile, titanite and hornblende are sparse. Plagioclase $\left(A n_{13-6}\right)$ is poikiloblastic owing to the abundance of preferentially oriented epidote inclusions. Low-Fe epidote also occurs as parallel arranged grains in the groundmass. Garnet $\left(\mathrm{Alm}_{56-54}-\mathrm{Grs}_{25-30}-\operatorname{Prp}_{18-11}\right)$ is tectonically dispersed within polymineral layers. Epidote gneiss occurs as interlayers in the amphibolites.

Pinkish granite (Fig. 3C) is composed of K-feldspar/alkali feldspar, albite $\left(A n_{5-1}\right)$, phengitic mica, a few relicts of Ca-low almandine-pyrope garnet ( $\operatorname{Alm}_{60-61}-\operatorname{Prp}_{32-35}-\mathrm{Grs}_{2-5}$ ), scarce apatite and allanite. The three latter minerals form occasionally large, densely packed aggregates. Epidote is very sparse or absent. In the alkali feldspar, the K-component increases toward the rims. $K f s$ also forms embayments or extensively replaces albite, appears as inclusions in phengitic mica and in albite and develops intergrowths with quartz. On the other hand, $k f s$ itself contains inclusions of albite, mica and quartz. The pinkish granite is an unfoliated and practically ductilely unstrained rock, evidently the youngest lithological variant in Rz2. It penetrated the country rocks both as sills and dykes along fracture zones.

Volumetrically dominant amphibolite is a massive coarse to medium-grained garnet-poor rock (type 1), possibly derived from a gabbroic protolith (Fig. 4A). It consists mainly of Ca-amphibole, plagioclase $\left(A n_{22-5}\right)$, low-Fe epidote both in the groundmass and as inclusions in plagioclase, titanite and \pm almandine-grossular garnet (Alm $\left.{ }_{58-56}-\mathrm{GrS}_{29-27}-\mathrm{Py}_{12-11}\right)$, compositionally similar to that in the epidote gneisses.

Amphibolite type 2 is a relatively fine-grained rock (Fig. 4B), presumably derived from basaltic protolith, also composed of Ca-amphibole, plagioclase (larger grains $A n_{20-10}$; small groundmass grains $\left.\mathrm{An}_{6-3}\right)$ and abundant garnet $\left(\mathrm{Alm}_{59-55^{-}} \mathrm{Grs}_{23-20^{-}}\right.$ $\left.-\mathrm{Py}_{18-16}\right)$ but scarce epidote and titanite. Conventional P-T estimates for amphibole-plagioclase pairs show that metamorphism occurred at temperatures of $570-615^{\circ} \mathrm{C}$ (geothermometry of Holland and Blundy, 1994) and pressure of 9-10 kbar (Plyusnina, 1982; Schmidt, 1992) in the case of the amphibolite types studied (unpublished data, in prep., 2019).

Amphibolites, mainly type 1 , pass into striped and migmatitic amphibolites due to the increasing contents of felsic minerals and white mica (Figs. 3D and 5). The neosome layers are relatively coarse-grained rocks composed of quartz and feldspars (PI + Kfs) accompanied by $m s$ and $h b l$ in variable amounts, thus grading to $h b /$-gneisses/granodiorites. In the migmatites, mesosome, melanosome and leucosome portions are discernible (Fig. 5A).

The neosome in the migmatized amphibolites generally formed prior to intrusions of K-granite. Scarce yet coarse Mghornblende blasts, riddled with drop-like quartz, phengite and garnet inclusions are dispersed in the leucocratic groundmass. Large, densely twinned, poikilitic plagioclase $\left(\mathrm{An}_{10-2}\right)$ grains are associated with thick quartz layers made also of coarse subpolygonal, almost unstrained grains or of markedly elongate grains. There is subordinate phengite and garnet (Alm58-55-Grs $\left.{ }_{30-27}-\mathrm{Py}_{16-11}\right) \pm$ epidote $\left(\mathrm{Ps}_{7-5}\right)$. The felsic minerals are corroded or coated by $k f s$ which also forms irregular grains and veinlets.

The data collected show that metamorphism slightly preceded migmatization. Migmatization in the amphibolites was accomplished by development of stripes composed/enriched in quartz, albite, epidote and phengite while the mafic groundmass consists of more densely packed amphibole but less feldspar (oligoclase). Striped amphibolites were produced by syntectonic metamorphic segregation. The process was remarkably enhanced by penetration of alkali-bearing fluids and facili- 

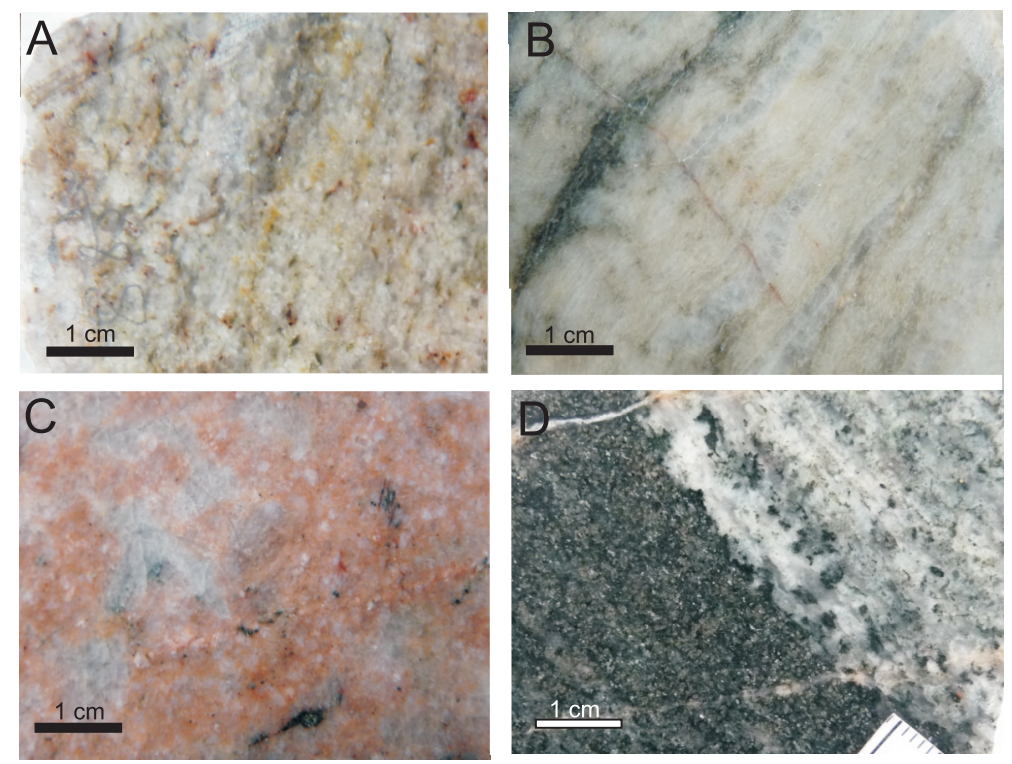

Fig. 3. Felsic rocks

A - pl-ms gneiss, depth of $885 \mathrm{~m}$; $\mathbf{B}-$ ep-gneiss depth of $928 \mathrm{~m}$; C - pinkish K-granite, depth of $955 \mathrm{~m}$; D - neosome in migmatized amphibolite, depth of $920 \mathrm{~m}$
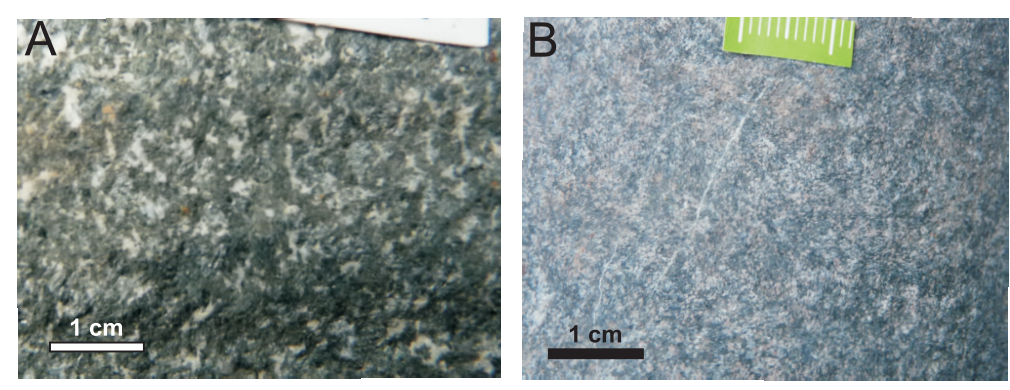

Fig. 4. Mafic rocks

A - epidote amphibolite (type 1), depth of $895 \mathrm{~m}$;

B - garnet amphibolite (type 2), depth of $943 \mathrm{~m}$


A - mesosome, fine-grained melanosome and coarse-grained leucosome/neosome (grading to $\rightarrow h b l$ gneiss) layers, while a later extensional shear zone cross-cuts the migmatitic layering (red arrow), depth of $918 \mathrm{~m}$; B - syntectonic thin leucosome layers segregated with fluid assistance in a contractional regime (upper arrows: T-gash, lower arrows: thrust), depth of $898 \mathrm{~m}$; C - thicker syntectonic segregations with fluid-promoted coarse-grained (re)crystallized layers cut by S-C' "normal" shear (arrrow), depth of $936 \mathrm{~m}$; mel - melanosome, mes - mesosome, leuc leucosome; arrows - shear sense 
tated by shear-promoted channels. Large felsic and mafic mineral blasts and common enrichment in albite component in migmatitic neosomes as well as albitic/alkali-feldspar rims on plagioclase grains in all these rocks indicate a general activity of volatiles and $\mathrm{K}$-carrying fluids in the formation of the neosome (unpublished data, in prep., 2019). The K-carrying fluids were presumably connected with the same source that released the $\mathrm{K}$-rich pinkish granite. Some 2-5 $\mathrm{m}$ thick granite layers that occur at the upper and lower portions of the borehole presumably represent apophyses which probably stemmed from a larger, more deep-seated, unfoliated granite body.

In the sector drilled, several discrete shear zones occur at various depths. These were earlier described as "signs of tectonic movements" (Burtan, 1962). In the metabasites, zonally more intense strain produced strongly pronounced foliation up to mylonites (Fig. 5B, C). Later deformation in semi-brittle conditions produced cataclastic zones. Felsic layers, specifically ep-gneisses, were relatively rheologically weaker and thus capable of localizing the imposed ductile deformation. Mica fishes, small folds and mineral lineation with up-slip kinematics testify to a contractional regime and syntectonic metamorphism/migmatization (Fig. 5B). An extensional overprint is documented by the S-C' fabric, narrow shear zones (Fig. 5A) and by small-scale normal faults (Fig. 5C).

\section{U-Pb GEOCHRONOLOGY}

\section{METHODS}

Zircon grains were separated from two samples (Fig. 2), Rz17 (neosome) and Rz18 (pinkish granite), using standard crushing, desliming, heavy liquid and paramagnetic procedures. Hand-selected zircon grains were placed onto double-sided tape, mounted in epoxy together with chips of the reference zircons (Duluth Gabbro - FC1), ground to approximately half-thickness and polished. Reflected and transmitted light photomicrographs were prepared for all zircons, as were cathodoluminescence (CL) Scanning Electron Microscope (SEM) images. These CL images were used to decipher the internal structures of the sectioned grains and to ensure that the $\sim 20 \mu \mathrm{m}$ SHRIMP spot was wholly within a single age component within the sectioned grains. The $\mathrm{U}-\mathrm{Th}-\mathrm{Pb}$ analyses were made using a Sensitive High Resolution Ion MicroProbe (SHRIMP II) at the Research School of Earth Sciences, The Australian National University, Canberra, Australia, following procedures given in Williams (1998, and references therein). Each analysis consisted of 6 scans through the mass range, with FC1 reference zircon grains analysed for every three unknown analyses. The data have been reduced using the SQUID Excel Macro of Ludwig (2001). The $\mathrm{Pb} / \mathrm{U}$ ratios have been normalised relative to a value of 0.01859 for the FC1 reference zircon, equivalent to an age of 1099 Ma (Paces and Miller, 1993). Uncertainties given for individual analyses (ratios and ages) are at the one sigma level (Appendix 1*). Wetherill concordia plots, probability density plots with stacked histograms and weighted mean ${ }^{207} \mathrm{~Pb} /{ }^{206} \mathrm{~Pb}$ age calculations, concordia ages and discordia regression intercepts were carried out using ISOPLOT/EX (Ludwig, 2003). All calculated ages are reported with uncertainties at $95 \%$ confidence limits.

For this study, in order to get more information about timing of the above-described migmatization and K-granite intrusion into the mafic rocks, zircons were separated from a neosome sample (Rz17) and from a pinkish granite (Rz18).

\section{ZIRCON SAMPLES}

The zircons from the migmatitic leucosome sample Rz17 are elongate, yellow-brown grains, with subrounded terminations. Most of the grains are cracked, but they do contain clear areas. The central parts are often dark and metamict, and there is a clear distinction between the clearer outer areas and the more metamict central parts to the grains. The CL images further highlight that distinction and reveal complex internal structures (Fig. 6A). In general, the outer parts of most grains are relatively homogeneous to weakly sector zoned. The central areas to grains 1,7 and 10, for example, are very dark, under $\mathrm{CL}$ subdued, often oval in shape. Thin, very bright $C L$ rims are present on many grains, but are $<10 \mu \mathrm{m}$ in width and too narrow to be analysed in the current study.

The zircons from the unfoliated K-granite sample Rz18 are notably equant to irregularly shaped grains and fragments of grains that are very clear under transmitted light. The CL images show a mostly subdued, relatively homogeneous internal structure, with minor oscillatory and sector zoning present in some grains (Fig. 6B).

\section{RESULTS}

SAMPLE Rz17

The analyses for the neosome sample Rz17 further highlight the complex nature of the zircon populations (Appendix 1 and Fig. 7A). Twenty-one areas have been analysed on 19 zircon grains. The analyses record a range of ${ }^{207} \mathrm{~Pb} /{ }^{206} \mathrm{~Pb}$ ages, with a scattered older grouping between $\sim 2570$ and $\sim 2765 \mathrm{Ma}$, and a near to concordant younger grouping at $\sim 2000 \mathrm{Ma}$. The two analyses on each of grains 5 and 12 provide a key to the understanding of the U-Pb systematics. Grain 12 has an essentially unzoned outer area which records a ${ }^{207} \mathrm{~Pb} /{ }^{206} \mathrm{~Pb}$ age of $\sim 2010 \mathrm{Ma}$. The dark CL, higher $U$ central area has $\mathrm{a}^{207} \mathrm{~Pb} /{ }^{206} \mathrm{~Pb}$ age of $\sim 2694 \mathrm{Ma}$. The low $\mathrm{U}$, thin outer rim to grain 5 and the high $U$ (dark $C L$ ) central component both record ${ }^{207} \mathrm{~Pb} /{ }^{206} \mathrm{~Pb}$ ages of $\sim 2575 \mathrm{Ma}$. In contrast to the results for grain 12 , the lower $U$ outer components to grains 1, 4, 6, 9 and 10 all record ${ }^{207} \mathrm{~Pb} /{ }^{206} \mathrm{~Pb}$ ages that are within the scattered Late Archean grouping. The rims and outer areas on grains $7,8,11,13,15$, 17 and 19 , together with that for grain 12 all record ${ }^{207} \mathrm{~Pb} /{ }^{206} \mathrm{~Pb}$ ages $\sim 2000 \mathrm{Ma}$. Those analyses range from concordant to $~ 5 \%$ discordant and a regression line fitted to the 8 analyses gives an upper intercept at $2005 \pm 6 \mathrm{Ma}$ (MSWD = 1.3; Fig. 7A). The lower intercept is within uncertainty of the present day, and the weighted mean of the ${ }^{207} \mathrm{~Pb} /{ }^{206} \mathrm{~Pb}$ ages for these 8 analyses is $2002.9 \pm 3.1$ (MSWD = 1.2; Fig. 7A).

In terms of the older areas/grains, the majority of the analyses are discordant, the oldest analysis is of grain 16 at

\footnotetext{
* Supplementary data associated with this article can be found, in the online version, at doi: $10.7306 /$ gq.1515
} 

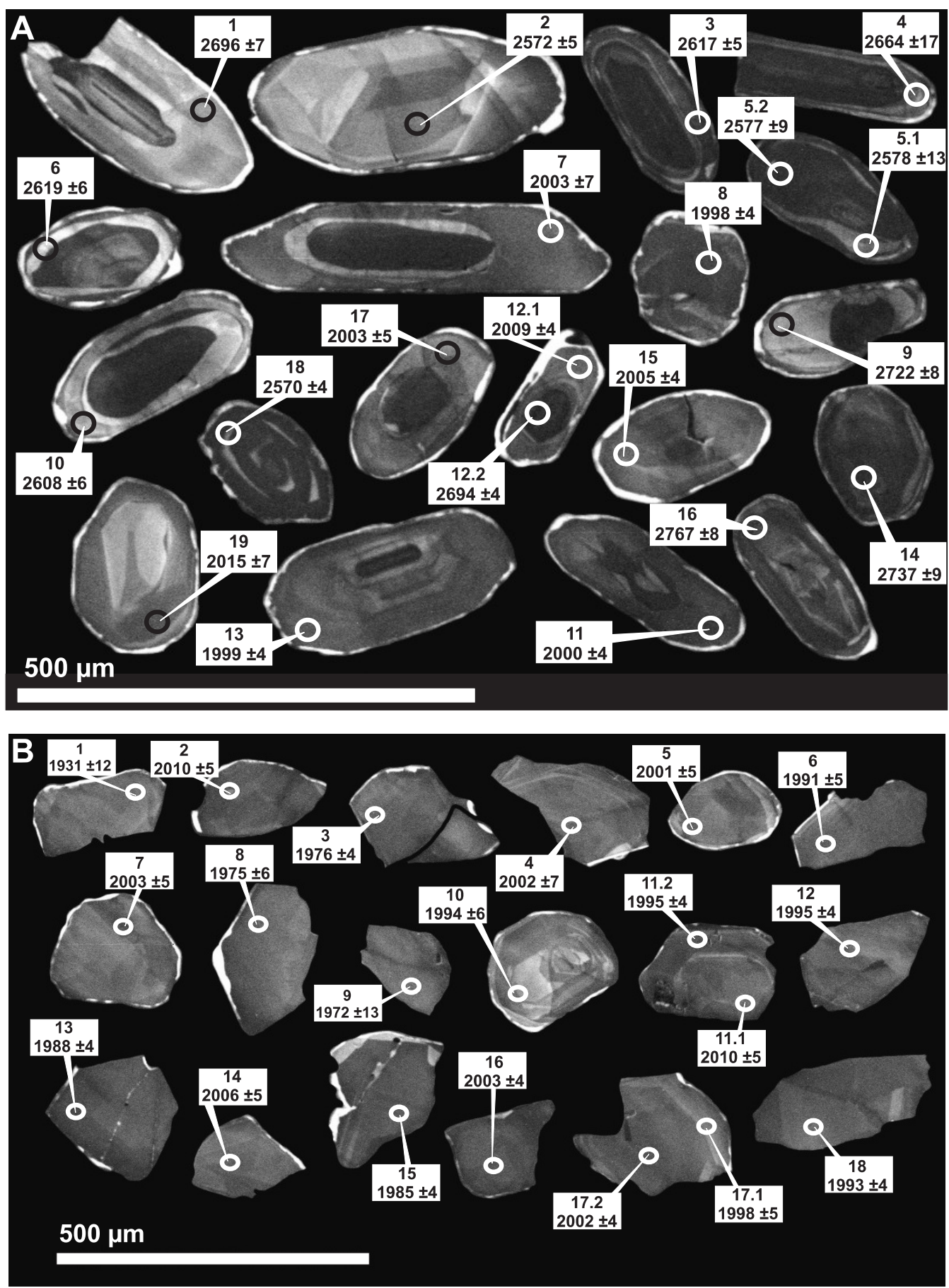

Fig. 6. BSE images of analysed zircons with analytical spots

A - neosome Rz17; B - K-granite Rz18

$\sim 2765 \mathrm{Ma}$ and is $\sim 10 \%$ discordant. On the concordia plot there appear to be several possible discordia lines, but no clearly defined lines of best fit. The areas analysed are considered to have undergone ancient and multiple radiogenic $\mathrm{Pb}$ loss episodes that gave rise to the scattering. However, there can be no doubt that there was a prominent Late Archean zircon crystallization event(s). The analysis of the coarser grain 2 together with the analyses of the structured grain 5 can be used to imply that the zircon crystallized $\sim 2570-2575 \mathrm{Ma}$.

The Th/U ratios for several of the areas giving the $\sim 2570$ to $\sim 2765 \mathrm{Ma}$ dates are notably low, $\sim 0.02$ (analyses 14.1 and
18.1) to $\sim 0.08$ (grain 4). These may imply that some of the zircon has a metamorphic paragenesis. In terms of the $\sim 2000 \mathrm{Ma}$ zircon component, the $\mathrm{Th} / \mathrm{U}$ ratios are between $\sim 0.22$ to $\sim 0.36$, and these values are common to crustal igneous zircon.

\section{SAMPLE Rz18}

The morphology and CL structure of the zircons from this sample of unfoliated granite show relatively simple igneous features (Fig. 6B). The 20 areas analysed on 18 zircon grains range from concordant to $\sim 10 \%$ discordant, with ${ }^{207} \mathrm{~Pb} /{ }^{206} \mathrm{~Pb}$ 


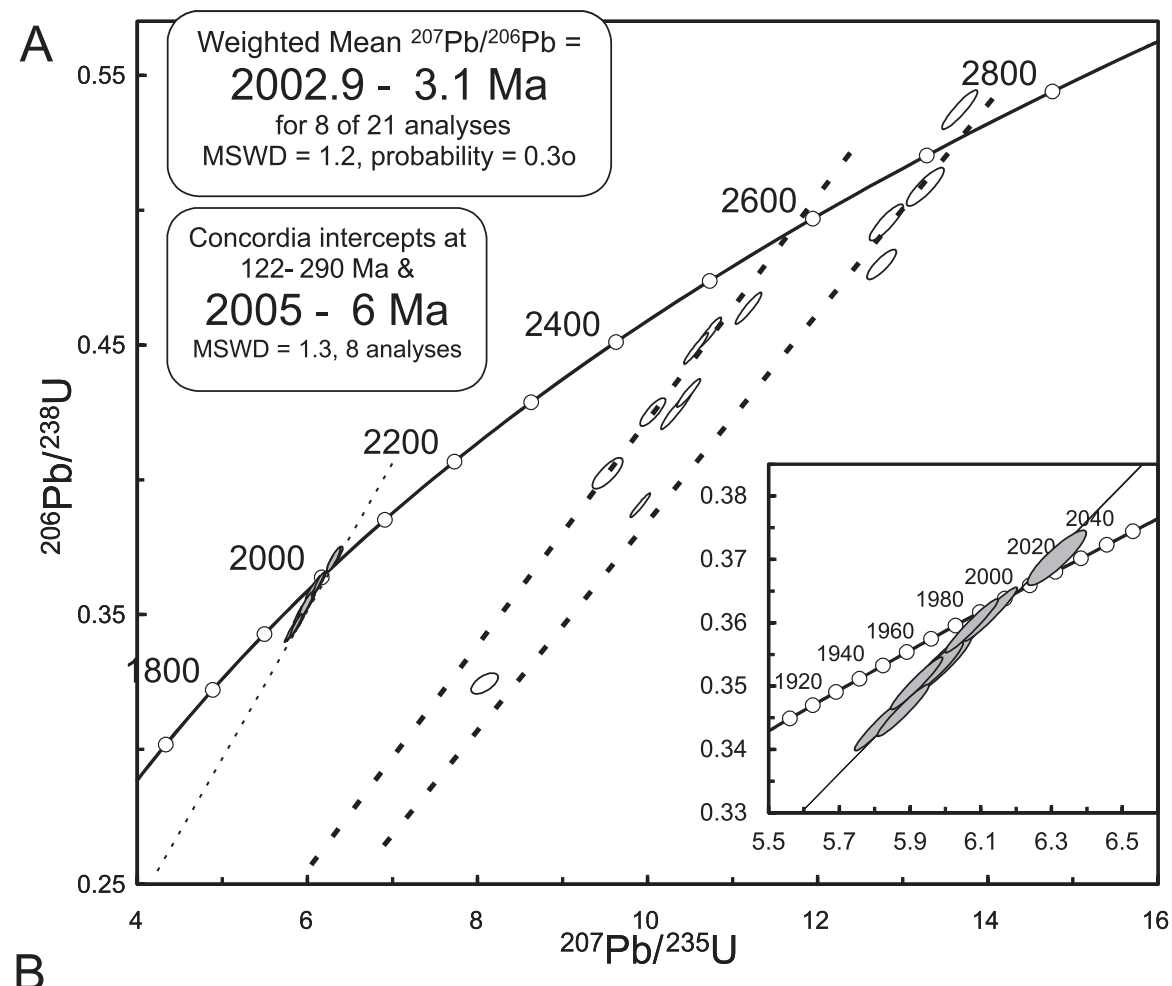

B

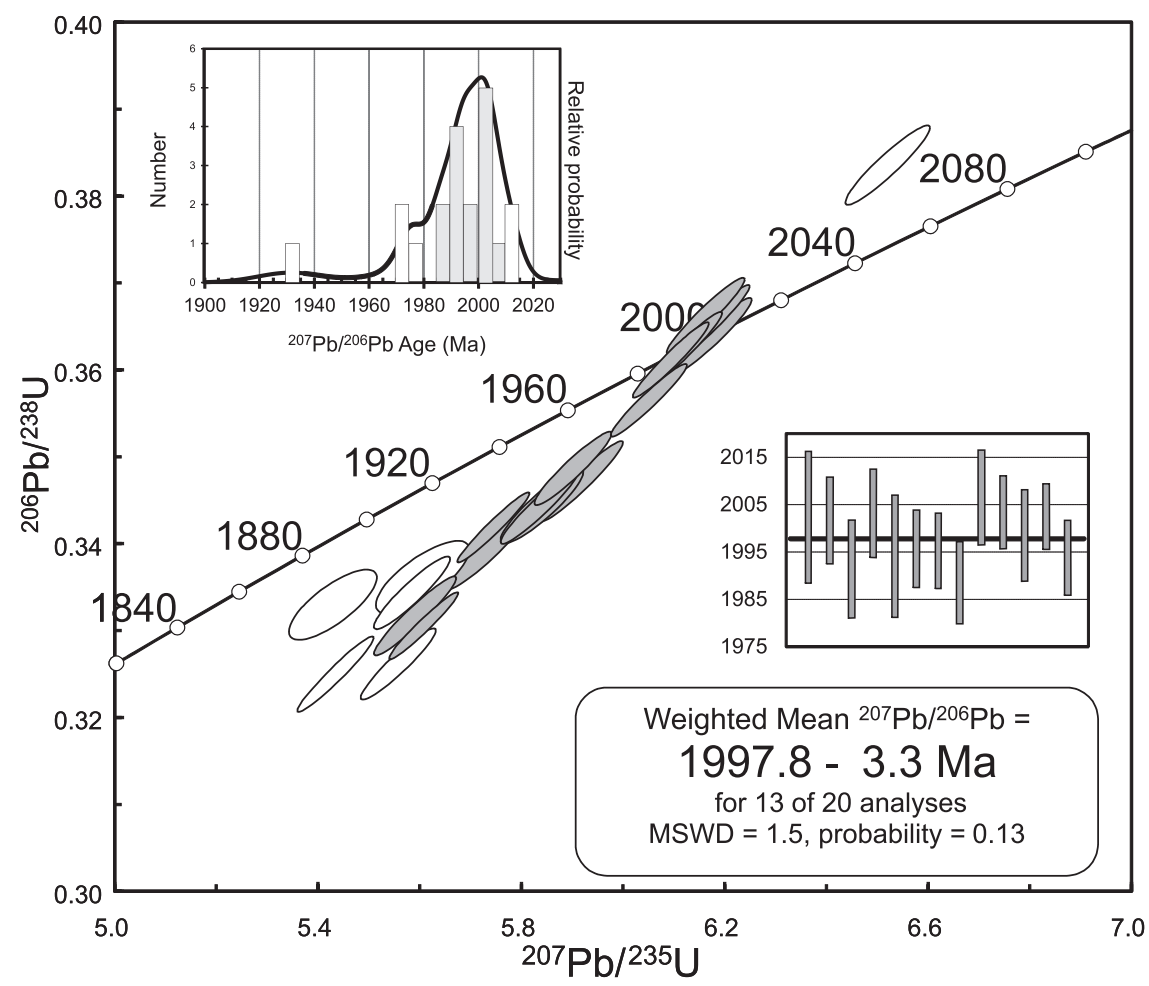

Fig. 7. Concordia plots of zircons

A - neosome Rz17; B - K-granite Rz18

ages that are between $\sim 1930$ to $\sim 2010 \mathrm{Ma}$ (Appendix 1 and Fig. 7B). The areas analysed have moderate to high $U$ concentrations (up to $\sim 1235 \mathrm{ppm}$ ) and the $\mathrm{Th} / \mathrm{U}$ ratios are consistent with crustal igneous zircon $(\sim 0.18$ to $\sim 0.40)$. Unfortunately, despite the apparently simple internal structure, there is some scatter in the discordia array, and a regression line fitted to all 20 analyses has excess scatter (MSWD $=5.7$; plot not shown). This dispersion is highlighted on the probability density plot, with stacked histogram (see inset Fig. 7B), where the main grouping shows a notably asymmetric distribution, with tailing on both the older and younger age sides; mostly on the younger side. This distribution implies that there has been radiogenic $\mathrm{Pb}$ loss prior to the present day. An arbitrary selection of 13 of the 20 analyses indicates a possible weighted 
mean ${ }^{207} \mathrm{~Pb} /{ }^{206} \mathrm{~Pb}$ date of $1998 \pm 3 \mathrm{Ma}(\mathrm{MSWD}=1.5 \mathrm{Ma})$. This provides a constraint on the time of igneous crystallization in the K-granite which intruded into the Rzeszotary gneiss-amphibolite domain.

\section{DISCUSSION}

The new $U-P b$ zircon data for the Rzeszotary rocks suggests that they originated at $\sim 2.75-2.6 \mathrm{Ga}$. In an earlier study reported in an abstract by Bylina et al. (2000), zircon grains from a pl-ms gneiss yielded a U-Pb TIMS upper intercept age of $2.7 \mathrm{Ga}$, which corresponds with our results. Complete recycling of still older (metamorphosed?) crust cannot be entirely excluded, yet there is no evidence of $\mathrm{U}-\mathrm{Pb}$ zircon resetting. Although the geochemistry of the amphibolites points to mantle origin (unpublished data, in prep., 2019), the limited core material does not allow one to decide upon the primary relationships between precursors of the amphibolites and pl-ms gneisses. The observed presence of a few thin intercalations of amphibolite in the gneisses is ambiguous. These might represent mafic xenoliths entrapped by felsic magma on intruding or alternatively veins of mafic rocks that penetrated the earlier developed felsic edifice, whether granitic or gneissic. Such an edifice may have been derived via partial melting from a primitive basaltic protolith which was produced by earlier mantle melting (see Barker, 1979; Martin, 1993). In any case, the 2.75-2.6 Ga event must have produced zircon-carrying felsic rocks that contributed to the formation of the crust in Neoarchean times.

In Rzeszotary 2, more legible are the records of a subsequent major event that occurred at $2.0 \mathrm{Ga}$. The borehole cores revealed evidence of contractional deformation concurrent with broadly syntectonic metamorphism and migmatization. Striped amphibolites were produced by syntectonic metamorphic segregation notably enhanced by penetration of alkali-bearing fluids that assisted in the formation of the neosome. The epgneisses were also strongly affected by migmatization which was both preceded and followed by the localized ductile shearing. Such features along with the large grain-size indicate an active role of volatiles and K-carrying aqueous fluids. The metamorphic segregations were most likely accomplished in an open system, assisted by fluids and partial melting similar to the manner described by Bowes and Park (1966). Water and $\mathrm{K}$-ions may have come from alkali-carrying fluid infiltrations presumably connected with the formation of K-granite deeper in the crust, which intruded the Rzeszotary domain at $2.0 \mathrm{Ga}$ concurrently with migmatization. The composition of the granite points to a felsic precursor, probably metamorphic as indicated by $T h / U$ ratios in zircon. This notion is in line with relicts of pyrope-almandine garnet which has remained preserved in the granite. Such remains suggest that earlier HP felsic granulitic crust, or one including felsic granulites, was partially melted and the melt gave rise to granitic magma. Alternatively the formation of the granite may have been accomplished by dehydration partial melting of $h b l$-grt amphibolites, which seems less likely.

The potential field data and borehole observations suggest that the Rzeszotary Horst is built of predominantly felsic rocks. Our zircon ages show that these rocks did not undergo any legible thermal event after $2.0 \mathrm{Ga}$. In both the samples analysed, the zircons suffered radiogenic $\mathrm{Pb}$ loss at unconstrained times. This might be at least partly connected with Permo-Carboniferous magmatic activity in the area (Nawrocki et al., 2010; Mikulski et al., 2019), which would concur with the lower intercept at $290 \mathrm{Ma}$ (Fig. 7) and explain thin bright CL rims on some zircon grains.
The 2.75-2.6 Ga ages make a significant contrast to the remainder of the terrane of Brunovistulia. In tectonic terms, the Rzeszotary domain clearly belonged to the foreland of the Cadomian orogen preserved in Brunovistulia (Buła and Żaba, 2005; Buła et al., 2008; Żelaźniewicz et al., 2009). On the other hand, the Cadomian hinterland in Brunovistulia is built of Gondwana (Amazonia)-derived fragments that recorded (tectono)thermal events at $\sim 1.0,1.2,1.4-1.5 \mathrm{Ga}$ and $\sim 1.65-1.8 \mathrm{Ga}$ (Finger et al., 2000; Friedl et al., 2000; Żelaźniewicz et al., 2005, 2009). In view of that, the Rzeszotary part of Brunovistulia may be considered as an exotic fragment of another continental entirety which was composed of Neoarchean and Paleoproterozoic crust. Such continental crust after profound reworking in the course of the $\sim 2.0 \mathrm{Ga}$ event was then broken up and the resultant fragments became reassembled in Neoproterozoic times (Nawrocki et al., 2004; Żelaźniewicz et al., 2009). In view of the above, the ancestors of the Rzeszotary crustal pieces should be looked for among cratons that have carried records of both $\sim 2.75-2.6 \mathrm{Ga}$ and 2.0 $\mathrm{Ga}$ orogenic events. Records of events of such ages have been reported from some cratons. However, in the present-day state of knowledge, it is difficult to tell which craton the Rzeszotary domain was actually derived from, to be eventually incorporated into the Cadomian belt. The Neorchean-Paleoproterozoic age spectra found in the Rzeszotary 2 borehole cores are compatible with those recognized in areas as remote today as Tanzania and Dharwar, India but possibly also at shorter distances in the Osnitsk-Mikashevychi belt of the East European Craton.

In Tanzania, Khoza et al. (2013) suggested that subduction of the oceanic lithosphere and collision between the Zimbabwe and Kaapvaal cratons at 2.7-2.5 Ga were then continued at 2.2-1.9 Ga by transcurrent movements and crustal exhumation deciphered in the Limpopo belt (Manya et al., 2006).

From the Dharwar craton, India, island arc tholeiitic basalts of $\sim 2.7 \mathrm{Ga}$ age, compositionally akin to modern arc basalts (Manikyamba et al., 2004) and a still poorly known tectonothermal event at $2.0 \mathrm{Ga}$ (Bhaskar Rao et al., 1992) were reported too.

Still another candidate to contribute to the Rzeszotary terrain, located much closer in its present-day position, could be the 2.0-1.95 Ga Osnitsk-Mikashevychi igneous belt which embraced an island arc association of amphibolite facies rocks that were later cut by K-granite intrusions. The belt is a junction between two large cratonic segments of the East European Platform. It initially developed on the Sarmatia craton margin which eventually collided with Fennoscandia after subduction of the Belarus oceanic plate (Bogdanova et al., 2001, 2008; Garetsky and Karatayev, 2011). However, the 2.75-2.65 Ga units occur away from this margin (Lobach-Zhuchenko et al., 2017). Whatever the provenence of the Rzeszotary rocks was, they were very likely involved in the $2.1-1.8 \mathrm{Ga}$ global event that led to the amalgamation of the Paleoproterozoic supercontinent of Columbia (Zhao et al., 2002, 2011).

\section{CONCLUSION}

Searching for a cradle of the Rzeszotary Horst rocks requires more data about the geology of potentially parent terrains. Nevertheless, the records recognized of the $2.0 \mathrm{Ga}$ event in Rzeszotary may have very likely remained in the direct connection with the 2.1-1.8 Ga global event, which gave rise to the Columbia Supercontinent that was assembled in the Paleoproterozoic and broken up in the Mesoproterozoic (Zhao et al., $2002,2011)$. It is suggested that (meta)felsic-mafic rocks of the 
Rzeszotary terrain evolved in the course of this process. To summarize, the Rzeszotary Horst is built of 2.75-2.0 Ga rocks that are interpreted as derived from an ancient magmatic arc, as suggested by geochemical signatures (unpublished data, in prep., 2019), and a subsequent collisional/orogenic zone embraced by the Columbia Supercontinent. In Ediacaran times, fragments of Columbia, after the Rodinian epoch, became eventually incorporated into the Cadomian orogen as part of the foreland of the latter, and thus contributed to the formation of the composite terrane of Brunovistulia and now represent its oldest Neoarchean-Paleoproterozoic components.

Acknowledgements. We gratefully acknowledge support for this work that was available through the project of the National Science Centre, Poland, No. 2017/25/B/ST10/02927, though the initiation was owed to "Palaeozoic Accretion of Poland" PCZ-0721 (Ministry of Environment). F. Finger and P. Poprawa are thanked for thoughtful and constructive comments.

\section{REFERENCES}

Barker, F., 1979. Trondhjemite: definition, environment and hypotheses of origin. Developments in Petrology, 6: 1-11.

Bhaskar, Rao, Y.J., Sivaraman, T.V., Pantulu, G.V.C., Gopalan, K., Naqvi, S.M., 1992. Rb-Sr ages of late Archean metavolcanics and granites, Dharwar craton, South India and evidence for Early Proterozoic thermotectonic event(s). Precambrian Research, 59: 145-170.

Bogdanova, S.V., Page, L.M., Skridlaite, G., Taran, L.N., 2001. Proterozoic tectonothermal history in the western part of the East European Craton: ${ }^{40} \mathrm{Ar} /{ }^{39} \mathrm{Ar}$ geochronological constraints. Tectonophysics, 339: 39-66.

Bogdanova, S.V., Bingen, B., Gorbatschev, R., Kheraskova, T.N., Kozlov, V.I., Puchkov, V.N., Volozh, Y.A., 2008. The East European Craton (Baltica) before and during the assembly of Rodinia. Precambrian Research, 160: 23-45.

Bowes, D.R., Park, R.G., 1966. Metamorphic segregation banding in the Loch Kerry basite sheet from the Lewisian of Gairloch, Ross-shire, Scotland. Journal of Petrology, 7: 306-330.

Buła, Z., 2000. The Lower Paleozoic of Upper Silesia and Western Małopolska (in Polish with English summary). Prace Państwowego Instytutu Geologicznego, 171: 1-63.

Buła, Z., Habryn, R. eds., 2008. Atlas geologiczno-strukturalny paleozoicznego podłoża Karpat zewnętrznych i zapadliska przedkarpackiego (in Polish). Państwowy Instytut Geologiczny, Warszawa.

Buła, Z., Żaba, J., 2005. Pozycja tektoniczna Górnośląskiego Zagłębia Węglowego na tle prekambryjskiego i dolnopaleozoicznego podłoża (in Polish). Geologia i zagadnienia ochrony środowiska w regionie górnoślaskim. Materiały konferencyjne LXXVI Zjazdu Naukowego PTG Rudy k/Rybnika: 90-99.

Buła, Z., Jachowicz, M., Żaba, J., 1997. Principal characteristics of the Upper Silesian Block and Małopolska block border zone (southern Poland). Geological Magazine, 134: 669-677.

Buła, Z., Żaba, J., Habryn, R., 2008. Tectonic subdivision of Poland: southern Poland (Upper Silesian Block and Małopolska Block) (in Polish with English summary). Przegląd Geologiczny, 56: 912-920.

Burtan, J., 1962. Bore-hole Rzeszotary 2 (in Polish with English summary). Kwartalnik Geologiczny, 6 (2): 245-259.

Bylina, P., Żelaźniewicz, A., Dörr, W., 2000. Archean basement in the Upper Silesia Block: U-Pb zircon age from amphibolites of the Rzeszotary horst. Joint Meeting EUROPROBE and PACE projects, Zakopane 2000: 11-12

Cieśla, E., Wybraniec, S., Petecki, Z., 1993. Mapa magnetyczna Polski w skali 1:200 000 z komputerowym bankiem danych (in Polish). CAG Państwowy Instytut Geologiczny, Warszawa.

Dudek, A., 1980. The crystalline basement block of the Outer Carpathians in Moravia: Bruno-Vistulicum. Rozpravy České Akademie Věd, Řada mathematicko-přirodnickych Věd, 90: $1-85$.

Finger, F., Hanžl, P., Pin, C., Von Quadt, A., Steyrer, H.P., 2000. The Brunovistulian: Avalonian Precambrian sequence at the eastern and of the Central European Variscides? Geological Society Special Publications, 179: 103-112.
Friedl, G., Finger, F., Mcnaughton, N.J., Fletcher, I.R., 2000. Deducing the ancestry of terranes: SHRIMP evidence for South America-derived Gondwana fragments in central Europe. Geology, 28: 1035-1038.

Gartesky, R.G., Karatayev, G.I., 2011. A tectonogeodynamic model for the junction zone between the Fennoscandian and Sarmatian segments of the East European Platform. Russian Geology and Geophysics, 52: 1228-1235.

Hanžl, P., Janoušek, V., Soejono, I., Buriánek, D., Svojtka, M., Hrdličková, K., Erban, V., Pin, Ch., 2019. The rise of the Brunovistulicum: age, geological, petrological and geochemical character of the Neoproterozoic magmatic rocks of the Central Basic Belt of the Brno Massif. International Journal of Earth Sciences, 108: 1165-1199.

Haydutov, I., Yanev, S., 1995. The Protomoesian microcontinent of the Balkan Peninsula - a peri-Gondwanaland piece. Tectonophysics, 272: 303-313.

Heflik, W., Konior, K., 1974. The present state of knowledge concerning the crystalline basement in the Cieszyn-Rzeszotary area (in Polish with English summary). Biuletyn Instytutu Geologicznego, 273: 195-221.

Holland, T., Blundy, J., 1994. Non-ideal interactions in calcic amphiboles and their bearing on amphibole-plagioclase thermometry. Contribution to Mineralogy and Petrology, 116: 433-447.

Kalvoda, J., Leichmann, J., Babek, O., Melichar, R., 2003. Brunovistulian terrane (Central Europe) and Istanbul Zone (NW Turkey): Late Proterozoic and Paleozoic tectonostratigraphic development and paleogeography. Geologia Carpathica, 54: 139-152.

Kalvoda, J., Babek, O., Fatka, O., Leichmann, J., Melichar, R., Nehyba, S., Spacek, P., 2008. Brunovistulian terrane (Bohemian Massif, Central Europe) from late Proterozoic to late Paleozoic: a review. International Journal of Earth Sciences, 97: 497-518.

Khoza, D., Jones, A.G., Muller, M.R., Evans, R.L., Webb, S.J., Mensopust, M., the Samtex team, 2013. Tectonic model of the Limpopo belt: Constraints from magnetotelluric data. Precambrian Research, 226: 143-156.

Konior, K., 1974. Geological structure of the Rzeszotary elevation in the light of recent geophysical and drilling data (in Polish with English summary). Annales Societatis Geologorum Poloniae, 44: 321-375.

Królikowski, C., Petecki, Z., 1995. Gravimetric atlas of Poland. Państwowy Instytut Geologiczny.

Lobach-Zhuchenko, S.B., Ryborak, M.V., Saltykove, T.E., Sergeev, S.A., Lokhov, K.I., Bobrove, E.M., Sukach, V.V., Skublov, S.G., Berezhnaya, N. G., Albekov, A. Yu., 2017. The Archean formation of the Sarmatian continental crust. Russian Geology and Geophysics, 58: 1494-1517.

Ludwig, K.R., 2001. SQUID 1.02, A User's Manual; Berkeley Geochronology Center Special Publication, 2, Berkeley Geochronology Center Special Publication, 2455 Ridge Road, Berkeley, CA 94709, USA. 
Ludwig, K.R., 2003. User's Manual for Isoplot/Ex, Version 3.0, A geochronological toolkit for Microsoft Excel Berkeley Geochronology Center Special Publication, 4, Berkeley Geochronology Center, 2455 Ridge Road, Berkeley, CA 94709, USA.

Manikyamba, C., Kerrich, R., Naqvi, S.M., Ram Mohan, M., 2004. Geochemical systematics of tholeiitic basalts from the $2.7 \mathrm{Ga}$ Ramagiri-Hungund composite greenstone belt, Dharwar craton. Precambrian Research, 134: 21-39.

Manya, S., Kobayashi, K., Maboko, M.A.H., Nakamura, E., 2006. Ion microprobe $\mathrm{U}-\mathrm{Pb}$ zircon dating of the late Archaean metavolcanics and associated granites of the Musoma-Mara greenstone belt, northeast Tanzania: implications for the geological evolution of the Tanzania Craton. Journal of African Earth Sciences, 45: 355-366.

Martin, H., 1993. The mechanisms of petrogenesis of the Archaean continental crust-comparison with modern processes. Lithos, 30: 373-388.

Mikulski, S.Z., Williams, I.S., Markowiak, M., 2019. Carboniferous-Permian magmatism and Mo-Cu (W) mineralization in the contact zone between the Małopolska and Upper Silesia Blocks (south Poland): an echo of the Baltica-Gondwana collision. International Journal of Earth Sciences, 108: 1467-1492.

Nowak, J., 1927. Zarys geologii Polski (in Polish). II Zjazd Stow. Geol.-Etnogr. Kraków: 1-160.

Nawrocki, J., Żylińska, A., Buła, Z., Grabowski, J., Krzywiec, P., Poprawa, P., 2004. Early Cambrian location and affinities of the Brunovistulian terrane (Central Europe) in the light of palaeomagnetic data. Journal of the Geological Society, 161: 513-522.

Nawrocki, J., Krzemiński, L., Pańczyk, M., 2010. ${ }^{40} \mathrm{Ar}-{ }^{39} \mathrm{Ar}$ ages of selected rocks and minerals from the Kraków-Lubliniec Fault Zone, and their relation to the Palaeozoic structural evolution of the Małopolska and Brunovistulian terranes (S Poland). Geological Quarterly, 54 (3): 289-300.

Petrascheck, W., 1909. Ergebnisse neuer Aufschlüsse im Randgebiete des galizischen Karbons. Verhandlungen der Geologischen Bundesanstalt, 16: 366-378.

Plyusnina, L.P., 1982. Geothermometry and geobarometry of plagioclase-hornblende bearing assemblages. Contribution to Mineralogy and Petrology, 80: 140-146.

Schmidt, M.W., 1992. Amphibole composition in tonalite as a function of pressure: an experimental calibration of the Al-inhornblende barometer. Contributions to Mineralogy and Petrology, 110: 304-310.

Whitney, D.L., Evans, B.W., 2010. Abbreviations for names of rock-forming minerals. American Mineralogist, 95: 185-187.

Williams, I., 1998. U-Th-Pb geochronology by ion microprobe. Reviews in Economic Geology, 7: 1-35.

Zhao, G.C., Cawood, P.A., Wilde, S.A., Sun, M., 2002. Review of global 2.1-1.8 Ga orogens: implications for a pre-Rodinia supercontinent. Earth-Sciences Reviews, 59: 125-162.

Zhao, G.C., Li, S.Z., Sun, M., Wilde, S.A., 2011. Assembly, accretion, and break-up of the Palaeo-Mesoproterozoic Columbia supercontinent: records in the North China Craton revisited. International Geology Review, 53: 1331-1356.

Żelaźniewicz, A., Nowak, I., Bachliński, R., Larionov, A.N., Sergeev, S.A., 2005. Cadomian versus younger deformations in the basement of the Moravo-Silesian Variscides, East Sudetes, SW Poland: U-Pb SHRIMP and Rb-Sr age data. Geologia Sudetica, 37: 35-52.

Żelaźniewicz, A., Buła Z., Fanning, C.M., Seghedi, A., Żaba, J., 2009. More evidence on Neoproterozoic terranes in southern Poland and southeastern Romania. Geological Quarterly, 95 (1): 93-124 